\title{
Fiscal Decentralization and Political Centralization in China
}

\author{
Implications for Growth and Inequality \\ Xiaobo Zhang*
}

August 2006

\begin{abstract}
China's current fiscal system is largely decentralized while its governance structure is rather centralized with strong top-down mandates and a homogenous governance structure. Due to large differences in initial economic structures and revenue bases, the implicit tax rate and fiscal burdens to support the functioning of local government vary significantly across jurisdictions. Regions initially endowed with a broader nonfarm tax base do not need to rely heavily on preexisting or new firms to finance public goods provision, thereby creating a healthy investment environment for the nonfarm sector to grow. In contrast, regions with agriculture as the major economic activity have little resources left for public investment after paying the expenses of bureaucracy. Consequently, differences in economic structures and fiscal burdens may translate into a widening regional gap.
\end{abstract}

Keywords: Chinese economy, growth, fiscal decentralization, regional inequality

JEL classification: E62, H20, O40, P20

Copyright (C) UNU-WIDER 2006

* International Food Policy Research Institute (IFPRI), 2033 K Street NW, Washington DC 20006, USA. This study has been prepared within the UNU-WIDER project on Inequality and Poverty in China.

UNU-WIDER gratefully acknowledges the financial contributions to the research programme by the governments of Denmark (Royal Ministry of Foreign Affairs), Finland (Ministry for Foreign Affairs), Norway (Royal Ministry of Foreign Affairs), Sweden (Swedish International Development Cooperation Agency_Sida) and the United Kingdom (Department for International Development). 
The World Institute for Development Economics Research (WIDER) was established by the United Nations University (UNU) as its first research and training centre and started work in Helsinki, Finland in 1985. The Institute undertakes applied research and policy analysis on structural changes affecting the developing and transitional economies, provides a forum for the advocacy of policies leading to robust, equitable and environmentally sustainable growth, and promotes capacity strengthening and training in the field of economic and social policy making. Work is carried out by staff researchers and visiting scholars in Helsinki and through networks of collaborating scholars and institutions around the world.

www.wider.unu.edu publications@wider.unu.edu

UNU World Institute for Development Economics Research (UNU-WIDER)

Katajanokanlaituri 6 B, 00160 Helsinki, Finland

Prepared by TechBooks (www.techbooks.com) and by Adam Swallow at UNU-WIDER.

The views expressed in this publication are those of the author(s). Publication does not imply endorsement by the Institute or the United Nations University, nor by the programme/project sponsors, of any of the views expressed. 


\section{Introduction}

Transferring authority to lower levels of government, which have better knowledge of the local conditions and preferences and are under closer scrutiny by their constituencies, is expected to improve the provision of local public goods and services (Dethier, 1999; Bardhan, 2002). Tiebout (1956) argues that under fiscal decentralization and interjurisdictional competition, citizens can vote with their feet to allocate themselves according to their preference to a package of local public goods and taxes. In other words, fiscal decentralization can prompt more efficient provisions of local public goods if individuals can freely move across localities. In addition to the sorting and matching role, Qian and Roland (1998, QR for short hereafter) emphasize that fiscal decentralization can also serve as a disciplinary device to preserve market incentives. These theories highlight the positive role of fiscal decentralization and interjurisdictional competition on the efficiency of public goods provision. In the past two decades, decentralization has become a global trend. However, empirical evaluation on the impact of decentralization on growth and distribution in developing countries is still in its infancy (Bardhan, 2002).

China, like many developing countries, has undergone a process of fiscal decentralization. ${ }^{1}$ The sheer size of China provides a good ground to test the predictions of the theories in the context of development. Using provincial data up to 1993, Lin and Liu (2000) provide empirical evidence that decentralization is conductive to growth. Zhang and Zou (1998), however, have found a negative relationship between growth and decentralization. Jin et al. (2005) reach a more optimistic finding that decentralization is not only good for growth but also for equity based on data up to 1992. Using data at a more microlevel, a few other studies (West and Wong, 1995; Park et al., 1996; Knight and Li, 1999) show that decentralization has a negative distributional effect. These studies are all based on data up to the early 1990s. Since then, more in-depth fiscal reforms have taken place and more comprehensive data have become publicly available. Therefore, it is important to extend the work to cover a longer period and more spatial units so as to reconcile the differences.

Compared to the decentralized fiscal system, China's political system is rather centralized and can be described as a multidivisional-form hierarchy structure (M-structure) (Maskin et al., 2000). Under this structure, the government can create a yardstick competition among local officials by rewarding or publishing them on the basis of economic performance. By examining the turnover data of top provincial leaders in China, Li and Zhou (2005) show that the internal political market also serves as a disciplinary mechanism for local officials to promote economic growth. Their finding suggests that the governance structure matters to economic growth in China.

In this study, we use a nationwide panel data set at the county level to more systematically investigate the distributional impact of decentralization by taking into account both the fiscal and governance structures. To our knowledge, this study is one

1 For detailed description on China's fiscal decentralization, see Tong (1998), Zhang (1999), and World Bank (2002). 
of the first attempts made with panel data at the county level. 2 The panel data set at the county level covering a more recent period provides a vehicle to reconcile the differences of empirical research on China's fiscal decentralization. The work is also a contribution to the literature. As Bardhan (2002) points out, few studies have empirically examined the performance of fiscal decentralization at the microlevel in developing countries.

The next section provides descriptive statistics of the data set used. Section 3 discusses the major theoretical arguments on decentralization. Section 4 presents empirical analysis and shows why the results are seemingly in contrary to the theoretical predictions. The last section ends with conclusion and policy implications.

\section{Data and descriptive analysis}

Through the 1980s and the early 1990s, China implemented a series of reforms to decentralize its fiscal system so as to provide more incentives for local government to promote economic growth (Lin and Liu, 2000). However, the decentralization led to widening fiscal disparity and shrinking central government revenues (World Bank, 2002). In 1994, the government introduced the tax sharing reform in order to boost the central revenues and enhance intergovernmental transfers.

In this study, we make use of a county-level public finance data set for our analysis. Since 1993, the China Statistical Bureau has published the China County Public Finance Statistical Yearbook. The yearbook contains detailed revenue, expenditure, gross value of industrial and agricultural output (GVIAO), population, and the size of public sector at the county level. There are over 2000 rural counties in China. Between 1993 and 2000, several hundred counties have changed their names or judiciary boundaries. We make an effort to match these counties, relying mainly on the official declarations on judiciary changes posted in the Ministry of Civil Affairs website. Because data for Tibet are largely missing, we drop Tibet in our analysis. In total, we have a panel of 1860 observations in 1993 and 2000.

Table 1 reports per capita revenues and expenditures as well as their compositions in percentage in the coast, inland, and for China as a whole in 2000.3 The per capita revenue and expenditure in the coastal region are 50 percent and 43 percent, respectively, higher than those in the inland region. 4 The difference in the source of revenues between the two regions is more noticeable than that in the shares of expenditures. Under the new tax sharing system local taxes are closely tied to the economic structures. As shown in the upper panel of the table, the more developed

2 Using the same data set Shih and Zhang (2004) examine the issue of transfers and subsidies and Tsui (2005) looks at the regional fiscal disparity.

3 The coastal zone includes Hebei, Liaoning, Shandong, Jiangsu, Zhejiang, Fujian, Guangdong, and Guangxi provinces; the inland zone comprises of all the remaining provinces. Kanbur and Zhang $(1999 ; 2005)$ have used the same classification.

4 The extra-budgetary items are not included in the official statistics. If the tax-sharing reform worsens the regressive tax structure, poor regions are more likely to stretch out grabbing hands and the paper's results maybe underestimated. Thanks are due to an anonymous referee for this point. 
regions can retain more revenues from the value-added tax, the business tax, the urban maintenance and construction tax, and the personal income tax which usually accrue to the secondary and tertiary sectors. In addition, the coastal region enjoys a higher percentage of tax rebates. By looking at the same data source, Tsui (2005) concludes that the regional fiscal disparity has worsened since the 1994 fiscal reform.

Table 1. Revenues and expenditures at the county level, 2000

\begin{tabular}{|c|c|c|c|}
\hline & Coast & Inland & China \\
\hline Revenues (yuan per capita) & 488.86 & 326.14 & 387.32 \\
\hline Value-added tax & 11.34 & 5.71 & 8.38 \\
\hline Business tax & 9.37 & 7.04 & 8.15 \\
\hline Personal income tax & 4.58 & 2.91 & 3.70 \\
\hline Urban maintenance and construction tax & 2.53 & 1.77 & 2.13 \\
\hline Agricultural taxes & 6.47 & 10.24 & 8.45 \\
\hline Revenue from enterprises & 7.37 & 4.27 & 5.74 \\
\hline Tax rebate & 18.22 & 11.50 & 14.69 \\
\hline Subsidies & 17.38 & 36.00 & 27.16 \\
\hline Miscellaneous revenues & 22.74 & 20.56 & 21.59 \\
\hline Expenditures (yuan per capita) & 467.10 & 326.58 & 379.41 \\
\hline Capital construction & 1.84 & 2.39 & 2.14 \\
\hline Supporting agricultural production & 3.59 & 3.02 & 3.28 \\
\hline $\begin{array}{l}\text { Operating expenses of agriculture, forestry, water } \\
\text { conservancy, and meteorology }\end{array}$ & 3.73 & 5.16 & 4.50 \\
\hline Education & 22.70 & 22.70 & 22.70 \\
\hline Social welfare & 1.45 & 2.43 & 1.97 \\
\hline Administrative expenses & 10.71 & 13.79 & 12.37 \\
\hline Public security & 5.42 & 5.47 & 5.45 \\
\hline Original-system remittances & 7.36 & 2.07 & 4.52 \\
\hline Earmarked remittances & 4.08 & 3.75 & 3.90 \\
\hline Miscellaneous expenditures & 39.12 & 39.22 & 39.17 \\
\hline
\end{tabular}

Note: $\quad$ Calculated by the author based on China County Public Finance Statistics Yearbook. Except for per capita revenue and expenditure, all the figures are in percentage. The figures in this table may appear to be slightly different from those in Table 1 of Tsui (2005) due to the difference in sample coverage. Our study focuses on rural counties while Tsui (2005) does not separate the rural counties from urban districts. In addition, we have made more concerted effort to match all the counties which have changed names or status from 1993 to 2000. 
Table 2 presents economic structure and tax rates for the two regions in 1993 and 2000. The agricultural tax rate is defined as the ratio of agricultural tax revenue to the gross agricultural output value, while the implicit industrial rate is measured as the ratio of tax revenues from the industrial sector relative to the gross industrial output value. Land rents include city construction tax and land user fees. Fiscal-dependent burden is denoted as the number of public employees per 10,000 yuan (1993 value) of local revenue. We use the national GDP deflator (1.977) to adjust GVIAO per capita, agricultural tax per capita, and land rent per capita to ensure that they are comparable between the two years.

Several features are apparent from Table 2. First, although both regions have experienced fast growth, the eastern region has grown at an annual rate of 3.81 percent, compared to 3.71 percent in the inland region, indicating a widening regional gap. The per capita GVIAO in the coast was about three times of that in the inland region in 2000. In addition, the share of agricultural output value in total GVIAO in the coastal areas was twice of that in the inland region.

Second, the tax rates in both agricultural and rural industrial sectors are regressive - the better-off coastal regions enjoy lower tax rates than the less developed inland regions. On a per capita basis, the distribution of agricultural taxes is rather even. However, because of the difference in economic base, the effective tax rates differ across regions. Figure 1 presents the implicit industrial tax rate against the logarithmic per capita GVIAO in 1993 and 2000. The downward straight line in the figure again clearly demonstrates that the industrial tax rate is regressive. The richer a county, the lower is its industrial tax rate.

Table 2. Economic structure and taxes, 1993 and 2000

\begin{tabular}{|c|c|c|c|c|c|c|}
\hline Year/Region & $\begin{array}{c}\text { Per capita } \\
\text { GVIAO }\end{array}$ & $\begin{array}{l}\text { Percentage } \\
\text { of } \\
\text { agricultural } \\
\text { output } \\
\text { value in } \\
\text { GVIAO }\end{array}$ & $\begin{array}{l}\text { Agricultural } \\
\text { tax rate } \\
\text { (yuan per } \\
100 \text { yuan) }\end{array}$ & $\begin{array}{l}\text { Industrial } \\
\text { tax rate } \\
\text { (yuan per } \\
100 \text { yuan) }\end{array}$ & $\begin{array}{l}\text { Agricultural } \\
\text { tax per } \\
\text { capita }\end{array}$ & $\begin{array}{l}\text { Land } \\
\text { revenue } \\
\text { per capita }\end{array}$ \\
\hline \multicolumn{7}{|l|}{1993} \\
\hline Coast & 6062 & 20.41 & 0.81 & 2.74 & 11.45 & \\
\hline Inland & 2050 & 41.54 & 1.15 & 5.95 & 11.18 & \\
\hline China & 3569 & 27.81 & 0.99 & 3.67 & 11.28 & \\
\hline \multicolumn{7}{|l|}{2000} \\
\hline Coast & 7876 & 19.20 & 1.06 & 0.80 & 37.91 & 8.01 \\
\hline Inland & 2646 & 37.21 & 1.72 & 1.30 & 39.12 & 3.89 \\
\hline China & 4612 & 25.65 & 1.40 & 0.94 & 38.67 & 5.44 \\
\hline
\end{tabular}


Figure 1. Economic development level and effective industrial tax rate
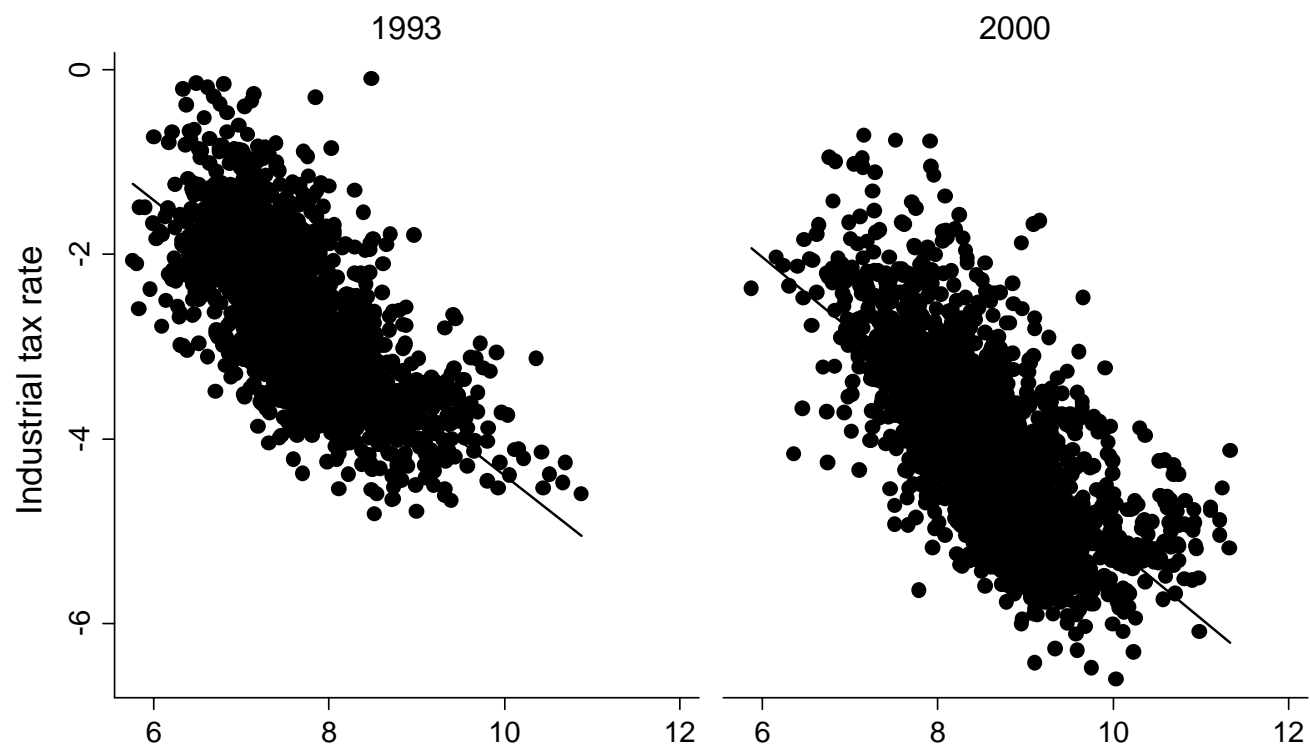

Economic development level

- Industrial tax rate (in log form) Fitted values

Graphs by year

Figure 2. Economic development level and rent from land development
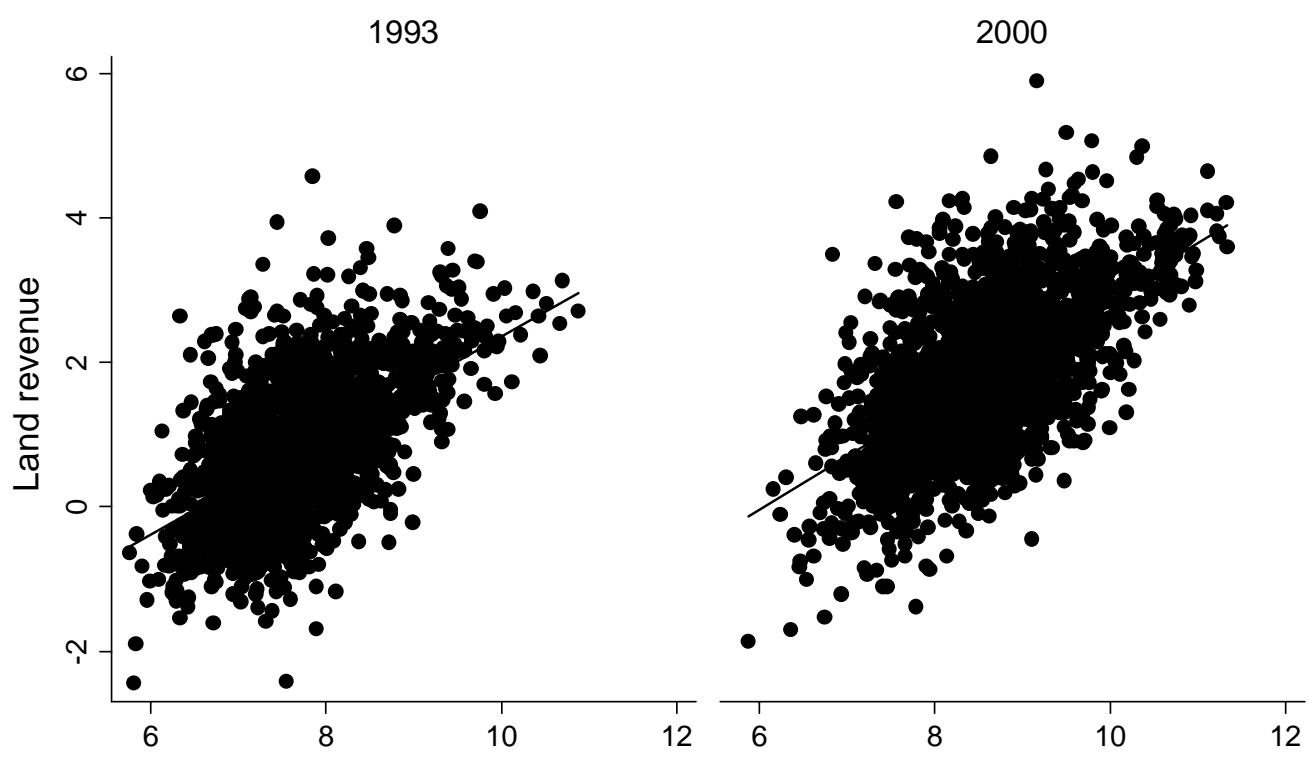

Economic development level

- Land revenue Fitted values

Graphs by year 
Third, the coastal region benefits more from the rising land value. The local revenue from city construction tax and land development in the coastal region is much higher than that in the inland region (Zhang, 2006). With a lower industrial tax rate, the rich region can attract more investments and migrants, which certainly boost the value of land. Figure 2 illustrates that land revenue is positively related to the level of economic development, consistent with the results for the two regions in Table 2. The rich regions can capitalize more from the rising land value than the poor regions.

Table 3 reports local government sizes and fiscal burdens to support the government. On average there are more than two persons on public payroll per hundred people and the ratio has increased between 1993 and 2000, indicating an inflating government size. The burden is heavier in the inland than in the coast. Because of the difference in tax base, the fiscal burden to support the local government is more unevenly distributed across regions. The number of people on public payroll per unit of local revenue in the inland region is significantly higher than that in the coastal region. As a result, the inland region spent a larger share on the administrative expenses and a smaller amount on productive public investment.

Table 3. Government size and fiscal burdens, 1993 and 2000

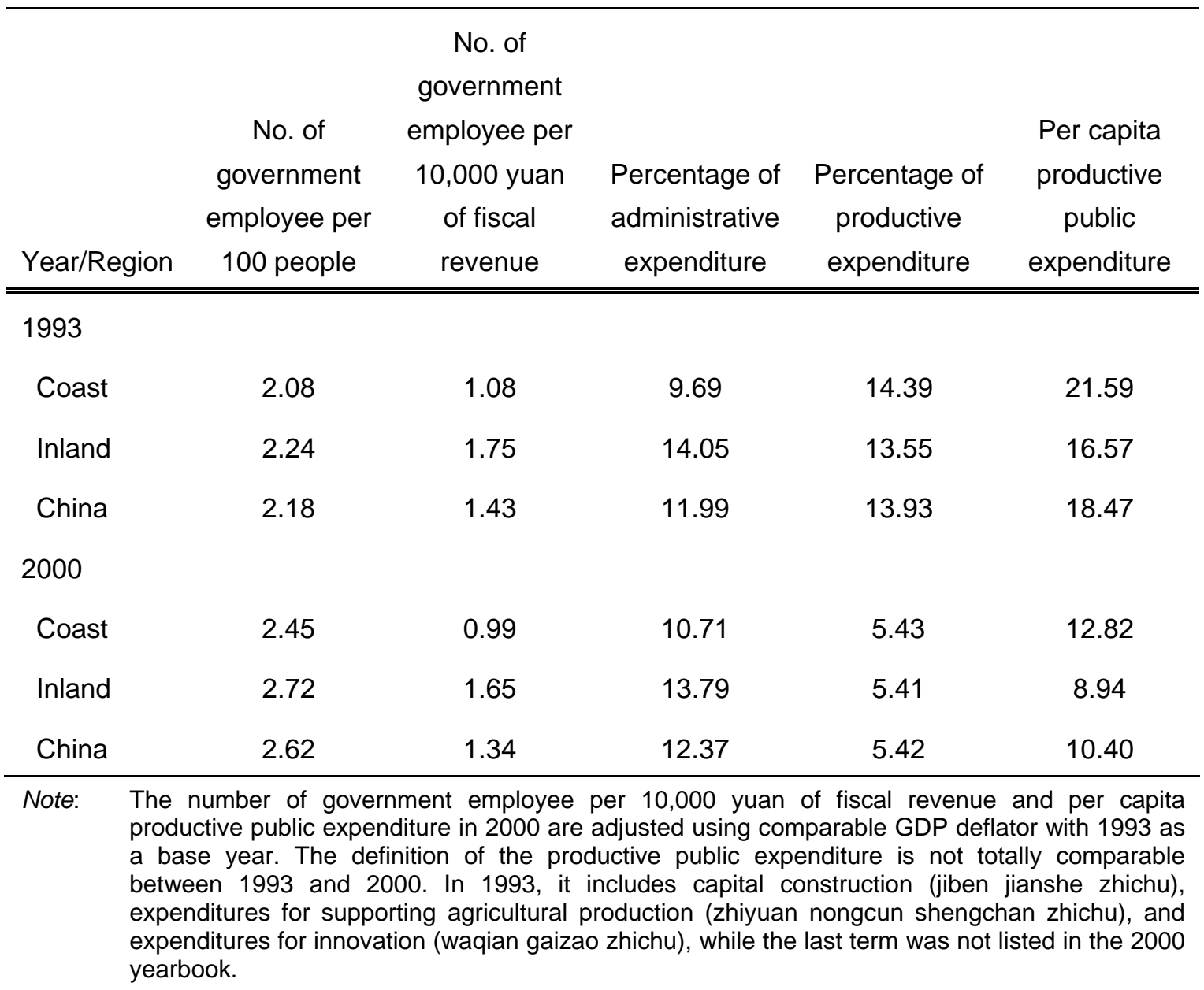




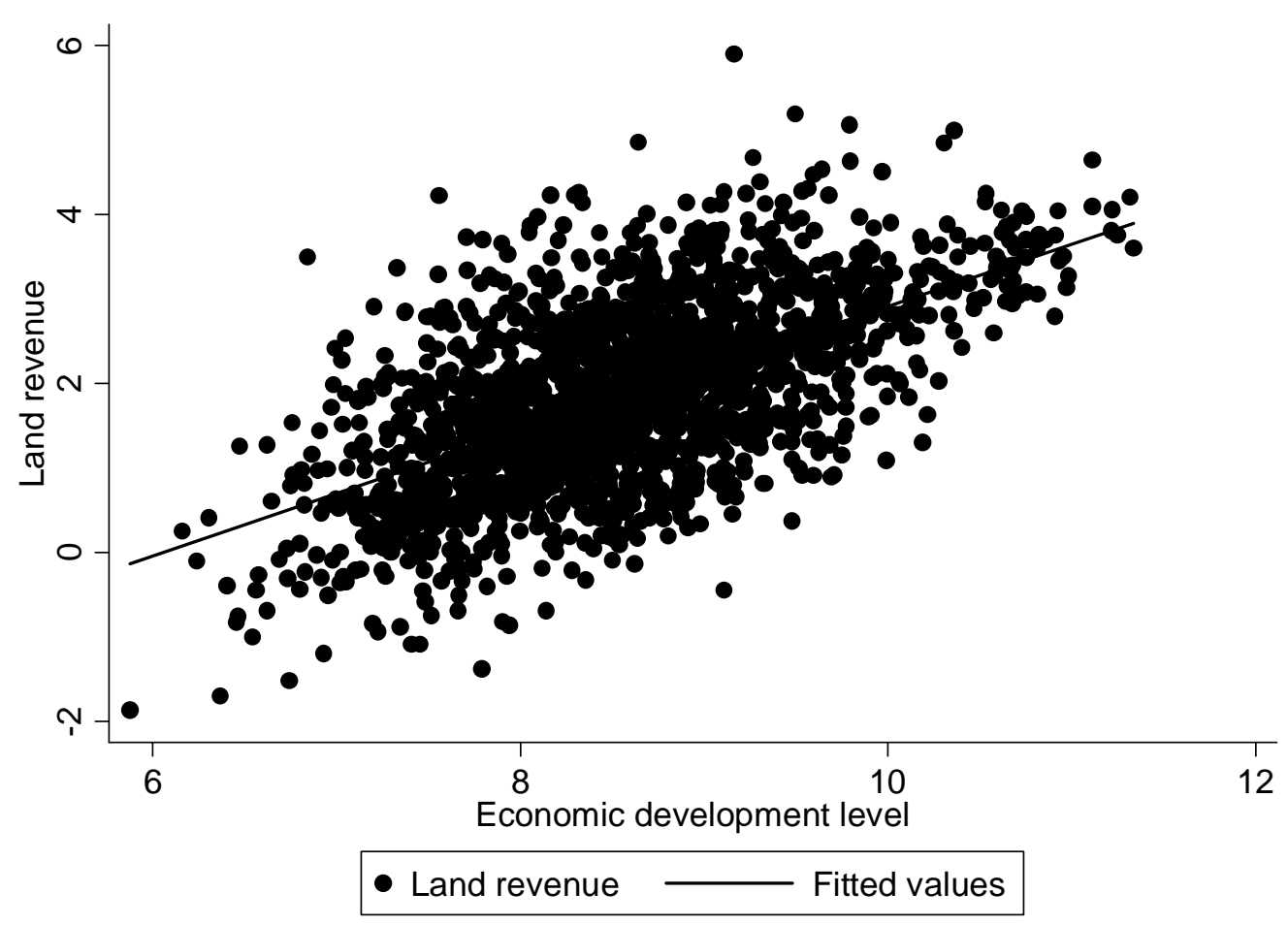

Note: The land revenue includes city maintenance and development tax and land using tax. Because in 1993 the land using tax was not published, the data in the figure are only for 2000. The vertical axis stands for the per capita land revenue in logarithmic form.

Figure 3 further highlights the correlation between fiscal-dependent burden and economic development. The negative relationship reveals that the revenue capacity to support the public payroll in poor counties is much weaker than in more developed ones. The government size, which is to a large extent in proportion to total population, is largely determined by the upper level government. The top priorities for the local government are collecting taxes, maintaining social order, and carrying over various tasks, such as agricultural industrialization and urbanization, assigned from the upper level governments (Lin et al., 2002). In the poor regions, the local government has little financial resources to carry over the task of public goods provision after covering the salaries of public employees.

To examine the dynamics of regional distribution, we further calculate the Gini coefficient of per capita GVIAO, per capita productive public expenditure, and the share of productive investment in total public expenditure, respectively, based on data the county level and present them in Table 4. All the three indicators show rising regional disparity. The Gini coefficient of per capita GVIAO rises from 46.47 to 48.39 . Figure 4 graphs the density distributions of logarithmic per capita GVIAO in 1993 and 2000, which clearly shows a spreading out over the period. Noticeably, inequality in the level and share of productive investment has increased by 7 percent and 27 percent, respectively, during the 7-year period, much higher than that in per capita GVIAO. 
Table 4. Gini coefficient of three indicators, 1993 and 2001

\begin{tabular}{lccc}
\hline Year & $\begin{array}{c}\text { Per capita } \\
\text { GVIAO }\end{array}$ & $\begin{array}{c}\text { Per capita productive public } \\
\text { expenditure }\end{array}$ & $\begin{array}{c}\text { Share of productive } \\
\text { investment in total } \\
\text { public expenditure }\end{array}$ \\
\hline 1993 & 46.47 & 68.28 & 33.04 \\
2000 & 48.39 & 73.34 & 41.82 \\
\hline Rate of change (\%) & 4.13 & 7.41 & 26.57 \\
\hline
\end{tabular}

Note: $\quad$ Calculated by the author based on China County Public Finance Statistics Yearbook. GVIAO stands for the gross value of industrial and agricultural output.

Figure 4. The density function of per capita gross industrial and agricultural output (log form)

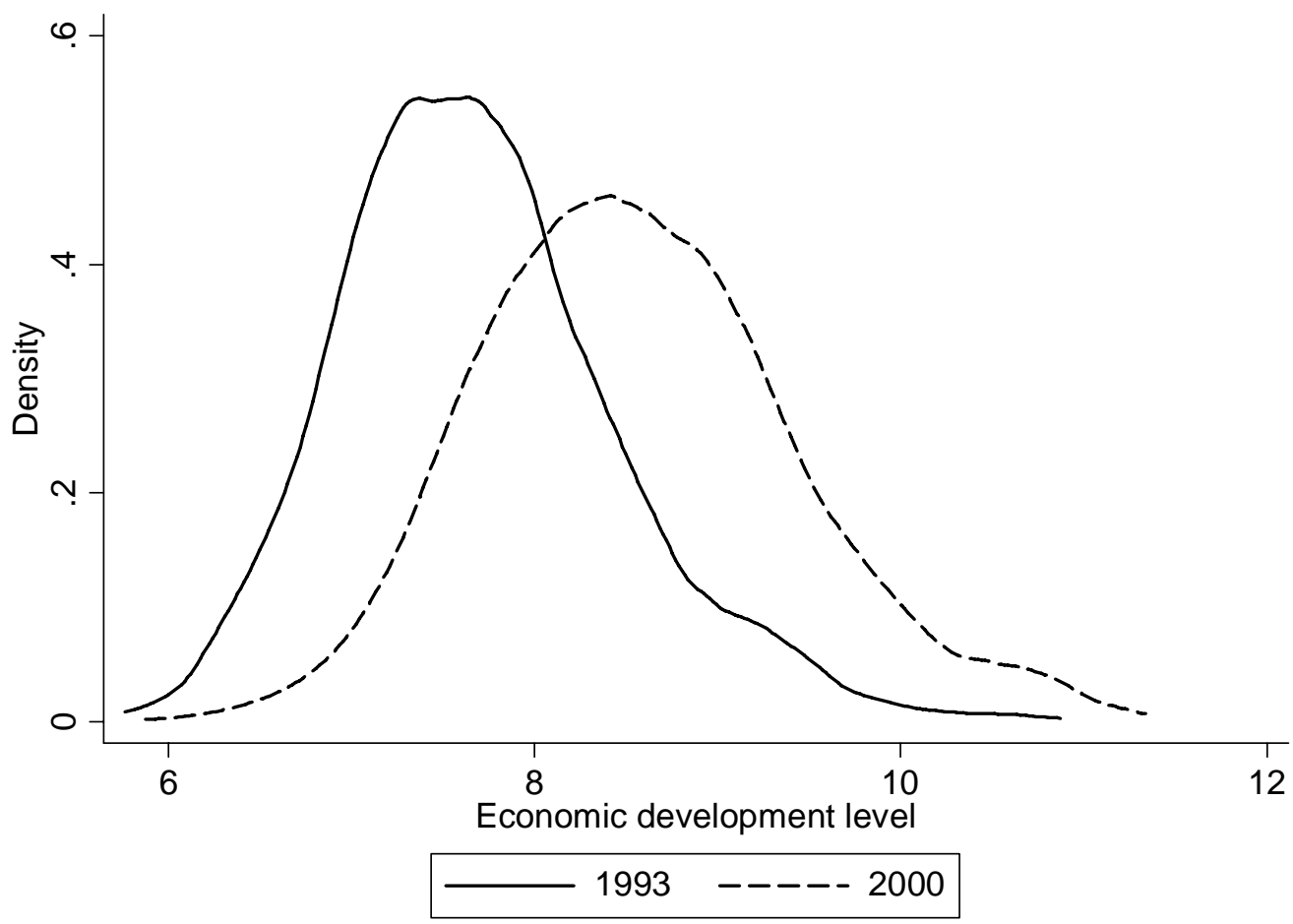

The uneven regional development in nonfarm activities in the rural sector has been regarded as one of the major driving forces behind the changes in rural regional inequality (Rozelle, 1994; Fan et al., 2004). Wan et al. (2004) and Zhang and Fan (2004) further show that the growing regional disparity in public capital significantly attributes to the rising regional inequality in nonfarm development largely because public capital is complementary to private capital. The evidence here offers an additional explanation: regions with higher implicit industrial tax rate have more difficulty attracting capital inflows than those with lower tax rates, thereby resulting in more fragmentation in capital markets and higher regional disparity. 
In short, the descriptive analysis shows that along with fiscal decentralization, regional distribution in public finance, in particular in productive public expenditure, has greatly deteriorated, contrary to what Jin et al. (2005) observed up to 1992. The results seem to be inconsistent with the theoretical predictions by Tiebout (1956) and QR (1998). In the next section, we provide a more quantitative examination on the impact of decentralization.

\section{Theoretical consideration}

Much of the literature on fiscal federalism, represented by Tibout (1956) and QR (1998), focuses on the economic efficiency aspect of market competition. In essence, the Tiebout model assumes full factor mobility. Bardhan (2002) comments that the assumptions underlying the Tiebout model are often too stringent in developing countries. In the case of China, despite loosening control of migration in recent years, there still exist obstacles to labor movement, in particular from rural areas to cities. Another implicit assumption of the Tiebout model is that local governments are responsive to the needs of voters. However, in China local government officials are in general not elected and their preferences may not be consistent with those of their constituents. In addition, the size of local governments is mainly determined by the upper level government and has much less to do with local needs. All these factors may make the Tiebout model inapplicable.

The QR federalism model has a crucial assumption that all the regions are identical. Within the more developed coastal areas, such as the Zhejiang province, where many counties share similar initial conditions, this assumption may hold. However, for China as a whole, regional differences, in particular between the inland and the coast, are substantial, making this assumption inappropriate.

Moreover, these theories do not take the transaction costs of tax collection and its consequences into account. As shown in the quote at the top of the first page, Adam Smith regarded fairness and economy in tax collection as fundamental principles. Regarding collection cost, he stated explicitly (1776: 1044):

Every tax ought to be so contrived as both to take out and to keep out of the pockets of the people as little as possible, over and above what it brings into the public treasury of the state.

In particular, he opposed levying a tax if it involves a great number of people whose salaries eat up a large share of the tax. In a less perfect world, labor migration involves costs, so do tax collection and policy implementation. In China's context, regions differ greatly in economic and taxation structures. As a result, the assumptions underlying the above two theoretical models may not be valid and the predictions of the above models may not bear out in reality.

Let us begin with a thought experiment. Suppose there are two regions, A (coast) and B (inland). Before the fiscal decentralization, region $\mathrm{A}$ is endowed with a large share of nonfarm economy while region $\mathrm{B}$ relies on agriculture as the major source of revenue. 
However, the administrative structures in the two regions are the same. 5 In addition, the average cost of collecting each unit of tax from a firm is much lower than that from a rural household. Consequently, both regions prefer to levy taxes on enterprises than on households if possible. After decentralization, both regions must be responsible for collecting their own revenues and fulfilling the same responsibilities or mandates. 6

In region $\mathrm{A}$, because of the large industrial base, the local government can obtain most revenues from the industrial sector. Moreover, a large industrial base means high opportunity cost of labor, making collecting taxes from rural households rather costly. If the incurred tax collection cost from households outweighs the revenue, it is more cost effective for the local government to forego farmers' tax obligations and pay the agricultural taxes to upper level governments using other revenue sources. When there are many local enterprises, the implicit taxation burden to each firm is relatively lower, which in turn help attract more business and enlarge the tax base. In addition, the current tax sharing scheme favors regions with larger share of the secondary and tertiary sectors as the value-added taxes and personal income taxes which are shared with the local government are largely linked to these sectors (Tsui, 2005).

Moreover, because the local government size is mainly related to the size of the population instead of the level of economic development, the government in region A has more local revenues disposable for productive public investment after covering the salaries of public employees. Better infrastructure and lower tax burdens can offset the relatively higher labor and land cost in region A. All these help create an enabling investment and form a virtuous cycle. In other words, in region A, the local government tends to stretch out helping hands to business development (Frye and Shleifer, 1997). This is a hypothesis we want to test.

In contrast, in region $\mathrm{B}$, there are few nonfarm enterprises. Because of lower tax collection cost on firms relative to agricultural taxes on households, the existing firms are more prone to be the predatory targets of their local government's excessive taxes and fees. Therefore, the implicit industrial tax rate tends to be high, which will discourage the entry of potential investment and drive away existing business enterprises, hampering the growth in the nonfarm sector over the long run. However, in China the size of local governments is rather fixed. After paying the salaries of public employees, local governments in poor regions often have little resources remaining to provide public investment. Low levels and quality of public infrastructure and service often result in unfavorable investment environment. Obviously, it is hard for any factory to operate normally and efficiently in an area plagued with irregular power outage and unpaved roads. Consequently, region B may have worse investment environment despite its lower wage rate and land rent. The large share of the agriculture sector means a higher collection cost of taxes on average because a higher level of manpower is required in the collection activities. Consequently we hypothesize that in region $\mathrm{B}$, the local governments tend to have grabbing hands.

5 Xu Yong (2003) has documented the evolution of administrative units in rural China and shown how excessive they are.

6 Liu and Tao (2004) list a set of central mandates and policy burdens. 
All in all, under fiscal decentralization, the transaction cost of tax collection and economic structure may affect the outcome of decentralization. As a result, the relationship between the local government and businesses may differ across regions. Because of the difference in initial economic structure and endowment, two equilibrium, one with helping hands and one with grabbing hands, may evolve as theorized by Cai and Treisman (2005). It is an empirical question to examine whether under fiscal decentralization the heterogenous revenue structure and homogenous government structure matter to the growth patterns.

\section{Quantitative analysis}

Now we use a more quantitative method to examine the impact of initial economic structure and fiscal-dependent burdens on subsequent local economic growth. Following Barro and Sala-I-Martin (1995) on growth convergence, we model the growth rate of per capita GVIAO as a function of its initial value, initial economic structure, fiscaldependent burdens, and a set of other variables:

$$
\log \left(\frac{y_{i t}}{y_{i t-1}}\right)=a+\beta \log \left(y_{t-1}\right)+\gamma Z+\delta D+\varepsilon_{i}
$$

where $y_{i t}$ is the per capita GVIAO. The subscripts $t$ and $t-1$ refer to 2000 and 1993, respectively. The left-hand side variable represents the growth rate of per capita GVIAO over the period. The coefficient $\beta$ stands for the speed of convergence of per capita GVIAO. A negative value for this coefficient indicates convergence while a positive value implies divergence. It provides useful information on understanding how initial conditions contribute to long-term growth and whether there is convergence or not. Because of diminishing returns to capital, in a perfect market, the returns to capital and labor will equalize across regions and lead to convergence. $Z$ includes the share of the gross value of agricultural output in GVIAO, the ratio of public employee to the total local revenue. These two variables are in logarithmic form. $\gamma$ is the corresponding coefficient for the two variables. $D$ is a set of dummy variables. If a county is nationally designated poor county, it is assigned a value of 1 and 0 otherwise. In different specifications, we also include prefecture and provincial fixed effects. $\delta$ is a vector of coefficients for these fixed effects.

Table 5 reports regression results under four specifications. The first three regressions include prefecture, provincial, and regional fixed effects, respectively. The last column excludes any dummy variables. The second to the last row presents the Akaike's information criterion (AIC) for model selection. The model with the smallest value is preferred. The AIC criterion suggests that the first regression with the prefecture fixed effects dominates the other three. Because we do not have county-specific price information, the fixed prefecture effects serve as a good proxy to eliminate the price effect inherent in the nominal growth of per capital GVIAO in the period. Moreover, they may capture other shocks common to a prefecture. 
Table 5. The effect of initial economic structure and government size on economic growth

\begin{tabular}{lcccc}
\hline Variables & $R_{1}$ & $R_{2}$ & $R_{3}$ & $R_{4}$ \\
\hline \hline Initial value in 1993 & $-0.467^{* *}$ & $-0.423^{* *}$ & $-0.384^{* *}$ & $-0.313^{* *}$ \\
& $(0.030)$ & $(0.027)$ & $(0.026)$ & $(0.025)$ \\
Economic structure in 1993 & $-0.340^{* *}$ & $-0.209^{* *}$ & $-0.211^{* *}$ & $-0.244^{* *}$ \\
(Agricultural gross output value/GVIAO) & $(0.084)$ & $(0.083)$ & $(0.080)$ & $(0.081)$ \\
Fiscal-dependent burdens in 1993 & $-0.125^{* *}$ & $-0.171^{* *}$ & $-0.165^{* *}$ & $-0.161^{* *}$ \\
(No. of employee on public payroll/total local revenue) & $(0.025)$ & $(0.025)$ & $(0.023)$ & $(0.023)$ \\
Nationally designated poor county status in 1993 & $-0.227^{* *}$ & $-0.243^{* *}$ & $-0.233^{* *}$ & $-0.233^{* *}$ \\
& $(0.028)$ & $(0.028)$ & $(0.030)$ & $(0.031)$ \\
\hline Regional dummies & Prefecture & Province ${ }^{* *}$ Region & None \\
\hline Omission variable test $(p$-value) & 0.336 & 0.037 & 0.086 & 0.046 \\
\hline AIC & 1681.5 & 2220.1 & 2598.8 & 2653.1 \\
\hline Adjusted $R^{2}$ & 0.536 & 0.290 & 0.117 & 0.090 \\
\hline Note: Coefficients for dummies are not reported here. The figures in the parentheses are standard \\
$\quad$ errors. The symbol means a significance level of 1 percent. & & &
\end{tabular}

Table 5 also presents the $p$-values of the regression specification error test (RESET) for omitted variables. Only the first specification with prefecture dummies accepts the null hypothesis that there are no missing variables. The other three regressions all reject the null hypotheses. As a result, the first specification is preferable.

The coefficient for the initial value of per capita GVIAO in all the three regressions is negative, suggesting the existence of a mean convergence. The coefficient for the share of agricultural output in the initial year of 1993 is statistically significant in all the three regressions, indicating that the heterogenous economic structure is an offsetting divergent force. For a region primarily relying on agricultural revenues, the subsequent growth in productive expenditure is slower than a region endowed with a large nonfarm tax base.

The negative and significant coefficient for the fiscal-dependent variable in 1993 suggests that oversized bureaucracy can be a real burden for local economic growth in poor regions. In an ideal Tibout world where local governments are responsive to the needs of constituents, lower revenues mean lower levels of public service and smaller government. Because of the nature of political centralization in China, the government size is rather inflexible, which leads to relatively heavier burdens in the poorer regions than in the richer regions under the arrangement of fiscal decentralization.

Table 5 also shows that those nationally designated poor counties are growing slower than other counties. This is consistent with the findings by Fan et al. (2004) on the 
performance of China's poverty alleviation program. There are several possible explanations. First, local governments in the poor countries may be more likely to understate their performance indicators so as to retain the designated-poverty status and qualify for transfers. Second, in the presence of central transfers, local officials may spend more time building up connections with the upper level governments rather than developing the local economy.

The coefficients for the dummy variables are not presented in the table to save space. They are jointly significant in the first three specifications. In the third specification, the coefficient for the inland coefficient is statistically negative. To check the robustness of the results, Table 6 lists the separate regression results for the coastal and inland regions. Except for the economic structure variable, the coefficients for other variables are rather robust. Within a prefecture in a coastal region, the economic structure is more homogenous. This is probably why the coefficient for this variable in the first regression is insignificant.

In short, fiscal decentralization may bring about detrimental distributional consequences when economic structure differs and government sizes are excessive.

Table 6. The effect of initial economic structure and government size on economic growth by region

\begin{tabular}{lcc}
\hline Variables & Coast & Inland \\
\hline \hline Initial value in 1993 & $-0.418^{* *}$ & $-0.503^{* *}$ \\
& $(0.062)$ & $(0.036)$ \\
Economic structure in 1993 & -0.153 & $-0.406^{* *}$ \\
(Agricultural gross output value/GVIAO) & $(0.160)$ & $(0.099)$ \\
Fiscal-dependent burdens in 1993 & $-0.198^{* *}$ & $-0.106^{* *}$ \\
(No. of employee on public payroll/total local revenue) & $(0.060)$ & $(0.028)$ \\
Nationally designated poor county status & $-0.229^{* *}$ & $-0.238^{* *}$ \\
\hline$R^{2}$ & $(0.070)$ & $(0.031)$ \\
\hline
\end{tabular}

Note: Coefficients for prefecture dummies are not reported here. The figures in the parentheses are standard errors. The symbol ${ }^{* *}$ means a significance level of 1 percent. 


\section{Conclusions and policy implication}

Considering the sheer size of China, fiscal decentralization is imperative for the government to tackle the information and incentive problems inherent in the relationship between the central and local governments. However, decentralization is a complex process involving not only fiscal aspects but also governance and mandates. When government sizes are largely independent of the demand of constituencies, the standard Tibout sorting model is no longer applicable.

Under the current local-central fiscal arrangement, the large regional variation in production patterns and revenue structures makes the underlying assumption of the QR fiscal federalism model invalid. Moreover, the transaction costs of tax collections become a more serious issue under fiscal decentralization. The high collection cost of agricultural tax plus the excessive government size makes local governments in regions endowed mostly with agricultural production barely able to provide the necessary public goods and services. Farmers and firms in poor regions are paying heavy taxes, while those in rich regions enjoy generous support and lower tax burdens. The regressive nature of the rural taxation system plays a significant role in explaining the divergent regional growth patterns even after controlling for the initial value. Overall, the fiscal decentralization is in favor of the rich localities and exacerbates the regional gap.

In his famous article, Oates (1968) has argued that to ensure the functioning of fiscal federalism, the central government should carry over the functions of stabilization and distribution, while the local government should be mainly responsible for performing the allocation role, i.e., a more efficient provision of public goods and service. In the case of China, however, the local government has to perform both the functions of distribution and allocation. By nature, it is almost impossible for local governments to equalize the fiscal capacity across regions in such a diverse country.

The large and inflexible size of local governments is another major impediment. Without a large reduction in the number of local public employees, especially in areas with agriculture as the major means of revenue, fiscal decentralization alone is not sufficient to deal with the distributional problem. Most theories on federalism assume that size and service of the local government are responsive to the needs of local residents. In a democratic society, voters endogenously determine the local government size. However, under the current system in China, if the central government grants more power to the local government and lets it determine the staffing level, it is likely that local government sizes in the less developed region will inflate rather than decrease. In a region lacking nonfarm job opportunities, entering the government payroll is one of the most attractive options, which may create a large rent-seeking behavior for officials to hire relatives and friends. Consequently, the size of local government is more likely to increase provided that the constituents do not have much say on local affairs. Therefore, how to control and reduce government sizes under the current political system poses a dilemma for policy markers. Economic decentralization in the reform period has undoubtedly helped prompt China's growth. But under the regime of political centralization, regional disparities have widened significantly. How to achieve balanced regional growth is a delicate task. Considering that China has been rather successful in engineering institutional innovations based on existing institutions, the challenge may induce more institutional innovations on fiscal decentralization and governance. 


\section{References}

Bardhan, Pranab, 2002. Decentralization of governance and development. Journal of Economic Perspective 16(4), 185-205.

Barro, Robert, Sala-I-Martin, Xavier, 1995. Economic Growth. McGraw-Hill, New York.

Cai, Hongbin, Tresman, Daniel, 2005. Does competition for capital discipline governments? Decentralization, globalization, and public policy. American Economic Review 95(3), 817-30.

China State Statistical Bureau, various years. China County Public Finance Statistical Yearbook. China Statistical Publishing House, Beijing.

Dethier, Jean-Jacques, 1999. Governance and economic performance: a survey. ZEF Discussion Paper 5 on Development Policy.

Fan, Shenggen, Zhang, Linxiu, Zhang, Xiaobo, 2004. Reform, investment and poverty in rural China. Economic Development and Cultural Change 52(2), 395-422.

Frye, Timothy, Shleifer, Andrei, 1997. The invisible hand and the grabbing hand. American Economic Review 87(2), 354-58.

Jin, Hehui, Qian, Yingyi, Weingast, Barry R., 2005. Regional decentralization and fiscal incentives: federalism, Chinese style. Journal of Public Economics 89(9-10), $1719-42$.

Kanbur, Ravi, Zhang, Xiaobo, 1999. Which regional inequality: rural-urban or coastinland? An application to China. Journal of Comparative Economics 27, 686-701.

Kanbur, Ravi, Zhang, Xiaobo, 2005. Fifty years of regional inequality in China: a journey through central planning, reform and openness. Review of Development Economics 9 (1), 87-106.

Knight, John, Shi, Li, 1999. Fiscal decentralization: incentives, redistribution and reform in China. Oxford Development Studies 27(1), 5-32.

Li, Hongbin, Zhou, Li-An, 2005. Political turnover and economic performance: the incentive role of personnel control in China. Journal of Public Economics 89, $1743-62$.

Lin, Justin Yifu, Liu, Zhiqiang, 2000. Fiscal decentralization and economic growth in China. Economic Development and Cultural Change 49(1), 1-21.

Lin, JustinYifu, Tao, Ran, Liu, Mingxing, Zhang, Qi, 2002. Urban and rural household taxation in China: measurement and stylized facts. CCER Working Paper.

Liu, Mingxing, Tao, Ran, 2004. Regional competition, fiscal reform and local governance in China. Paper presented in the Conference 'Paying for Progress. Public finance, Human Welfare, and Inequality in China'. May 21-23, Institute for Chinese Studies, Oxford.

Maskin, Eric, Qian, Yingyi, Xu, Chenggan, 2000. Incentives, scale economies, and organization form. Review of Economic Studies 67, 359-78.

Oates, Wallace, 1968. The theory of public finance in a federal system. Canadian Journal of Economics 1(1), 37-54. 
Park, Albert, Rozelle, Scott, Wong, Christine, Ren, Changqing, 1996. Distributional consequences of reforming local public finance in China. China Quarterly 147, 751-78.

Qian, Yingyi, Roland, Gerard, 1998. Federalism and the soft budget constraint. American Economic Review 88(5), 1143-62.

Rozelle, Scott, 1994. Rural industrialization and increasing inequality: emerging patterns in China's reforming economy. Journal of Comparative Economics 19, 362-91.

Shih, Victor, Qi, Zhang, 2004. Who receives subsidies: a look at the county-level before and after the 1994 tax reform. Paper presented in the Conference 'Paying for Progress. Public finance, Human Welfare, and Inequality in China'. May 21-23, Institute for Chinese Studies, Oxford.

Smith, Adam, 1776. The Wealth of Nations. Bantam Classic Edition/March 2003. Bantam Dell, New York.

Tiebout, Charles, 1956. A pure theory of local expenditures. Journal of Political Economy 64, 416-24.

Tong, James, 1998. Fiscal regimes in China, 1971-1998. Chinese Economy 31(3), $5-21$.

Tsui, Kai-yuen, 2005. Local tax system, intergovernmental transfers and China's local fiscal disparities. Journal of Comparative Economics 33(1), 173-196.

Wan, Guanghua, Lu, Ming, Chen, Zhao, 2004. Globalization and regional income inequality: evidence from within China. WIDER Discussion Paper 2004/10. Helsinki: UNU-WIDER.

West, Loraine A., Wong, Christine, 1995. Fiscal decentralization and growing regional disparities in rural China: some evidence in the provision of social services. Oxford Review of Economic Policy 11(4), 70-84.

World Bank, 2002. China National Development and Sub-national Finance: A Review of Provincial Expenditures. World Bank, Washington, DC.

$\mathrm{Xu}$, Yong, 2003. Xiangcun zhili jiegou gaige de zouxiang (Direction of reforms on rural governance). Zhanluo Yu Guanli (Strategy and Management) 4, 90-7.

Zhang, Le-Yin, 1999. Chinese central-provincial fiscal relationships, budgetary decline and the impact of the 1994 fiscal reform: an evaluation. China Quarterly 157, $115-141$.

Zhang, Tao, Zou, Heng-fu 1998. Fiscal decentralization, public spending and economic growth in China. Journal of Public Economics 67, 221-40.

Zhang, Xiaobo, 2006. Asymmetric property rights in China's economic growth. Development Strategy and Governance Division Discussion Paper 28. International Food Policy Research Institute (IFPRI), Washington, DC.

Zhang, Xiaobo, Fan, Shenggen 2004. Public investment and regional inequality in rural China. Agricultural Economics 30(2), 89-100. 